\title{
Attitudes of business leaders and professional ecologists toward corporate social funding of environmental conservation
}

\author{
G.R. Preston* and R.F. Fuggle \\ Department of Environmental and Geographical Science, University of Cape Town, Private Bag, Rondebosch 7700 \\ Republic of South Africa \\ W.R.Siegfried \\ Percy FitzPatrick Institute of African Ornithology, University of Cape Town, Private Bag, Rondebosch 7700 \\ Republic of South Africa
}

Received 8 May 1989; accepted 20 July 1990

\begin{abstract}
A study of South Africa's business leaders and professional ecologists reveals strong support for corporate social funding. However, the average level from after-tax profits considered appropriate for corporate social funding by business leaders (3\%) is appreciably lower than the ecologists' average of $14,5 \%$. Both business leaders and professional ecologists believe that environmental conservation deserves greater financial support than it currently receives. Education is rated as the most worthy sphere for corporate social funding by both groups. Whereas ecologists rate job creation and housing as of equal concern to environmental conservation, and health and welfare of lesser concern, business leaders rate them all as of greater worthiness for funding than environmental conservation. Both groups regard rural development as a less important target for funding (although the ecologists place a greater emphasis on this sphere than the business leaders do), and deem the arts and sport to be of low priority. The business leaders' preferences for funding follow their perceptions of the priority issues facing South Africa at present, whereas ecologists believe that such funding should be selective, rather than effectively being a back-up for government responsibilities. The expressed concern for support of population control, acknowledged to be the most serious conservation issue in South Africa at present, is offset by the low level of actual corporate support for this issue. Business leaders, in particular, claim that corporate social funding of environmental conservation is backed by shareholders.
\end{abstract}

'n Studie van die houdings van sakeleiers en professionele ekoloe toon sterk steun vir korporatiewe sosiale befondsing. Die gemiddelde vlak van wins na-belasting (3\%) wat sakeleiers egter as toepaslik vir korporatiewe sosiale befondsing beskou, is aansienlik laer as die ekoloë se gemiddeld van 14,5\%. Sakeleiers sowel as ekoloe glo dat omgewingsbewaring groter finansièle steun verdien as wat tans die geval is. Opvoeding word deur beide groepe beskou as die belangrikste area vir korporatiewe sosiale befondsing. Terwyl ekoloè werkskepping en behuising beskou as net so dringend as omgewingsbewaring, en gesondheid en welsyn as minder belangrik, beskou sakeleiers hierdie aspekte as van groter dringendheid as amgewingsbewaring. Beide groepe beskou landelike ontwikkeling as nie so 'n belangrike doelwit vir befondsing nie (alhoewel ekoloè 'n groter klem op hierdie aspek plaas as die sakeleiers), en die kunste en sport as 'n lae prioriteit. Die sakeleiers se voorkeure vir befondsing is gebaseer op hul persepsies van die dringende kwessies wat Suid-Afrika tans in die gesig staar, terwyl ekolos glo dat die dergelike befondsing selektief moet wees en nie regeringsverantwoordelikhede moet rugsteun nie. Teenoor die feit dat besorgdheid oor bevolkingsaanwas uitgespreek is en die beperking daarvan as die belangrikste omgewingskwessie tans in Suid-Afrika beskou word, staan die feit dat hierdie kwessie in werklikheid $\mathrm{min}$ korporatiewe steun ontvang. Veral sakeleiers beweer dat korporatiewe sosiale befondsing deur aandeelhouers ondersteun sal word.

*Author to whom correspondence should be addressed.

\section{Introduction}

Corporate social funding was one of the foci in a wideranging study of the attitudes of business leaders and professional ecologists toward conservation and development in South Africa (Preston, 1989; Preston, Fuggle and Siegfried, 1989//n Press). Corporate social funding (a more specific term than corporate social responsibility, as it is also called) was defined as 'a willingness to fund programmes to the benefit of society out of money that would otherwise be part of shareholders' profits'.

The hypothesis tested in this study was that there are significant differences between the attitudes of business leaders and professional ecologists toward conservation and development. Specifically, here, this would be manifested in their attitudes toward corporate social funding, and its distribution - particularly with respect to environmental conservation. Secondary hypotheses were that certain biographical variables are significant determinants of differences within the two groups (e.g., 'applied' versus 'research' ecologists; business leaders from 'primary impact' versus 'secondary impact' businesses).

Regard for the views of South Africa's business leaders lies in their being very influential individuals in decisions affecting corporate social funding, while the professional ecologists' views are of interest on account of their insight into the needs of environmental conservation. What is more, in providing factual knowledge of the attitudes of these two groups, the study facilitates the search for common ground between them.

Corporate social funding is a contentious issue in business circles, as evidenced by the apocryphal maxim, 'The business of business is business'. Milton Friedman (1962), one of the best-known proponents of a marketdriven society, asserts that 'Few trends could so 
thoroughly undermine the very foundation of our free society, as the acceptance by corporate officials of a social responsibility other than to make as much money for their stockholders as possible'. His contention is that maximizing profits for shareholders is what achieves the greatest good for society. Moreover, he questions the ability of corporate executives to select the best options, hence casting doubts on the efficiency of their social funding programmes. However, far from allowing Adam Smith's (1776) 'invisible hand' to regulate the morality of the free-market system, all of the top listed companies in South Africa are believed to support (to varying degrees) corporate social funding (Bower, 1989). Many would appear to adhere to the view that 'The issue of what constitutes the common good is not, and cannot be, decided by market forces alone' (Leath, 1984). Others may disagree in principle, but have nonetheless bowed to pressure to conform.

Some people claim that corporate social funding is merely as a form of advertising, the rewards of supporting a cause outweighing the costs of doing so. The South African Breweries sponsorship of sporting events, such as the Castle Currie Cup (cricket) and Lion Cup (rugby), is a case in point. The South African Breweries' attitude is that this money is a form of advertising (indeed, it is tax-deductible) and is divorced from their large, and low profile, funding programme (M. Kahn, pers. comm.). This echos the views expressed in a survey of the readers of the Harvard Business Review (Brenner and Molander, 1977), where only 23\% of the respondents agreed that 'social responsibility is good business only if it is also good public relations and/ or preempts government interference'.

The term corporate social funding was used with respect to funding outside of the company. Some people believe that the funding of in-house schemes (with money that would otherwise be part of shareholders' profits), such as scholarships and housing subsidies, also constitutes corporate social funding. In this study such intemal funding is not considered to be part of the corporate social funding, for shareholders are more likely to accept that such schemes are profitable for the company in the long term.

\section{Method}

The statistical universe used for the 'business leaders' was the managing directors of the top 100 industrial companies together with the top 100 companies by market capitalizating (Financial Mail, 1987), as well as the top non-listed (private or foreign-controlled) companies. Where there was no managing director, the chief executive or chairman was approached. The universe size was 138, and a sample of 100 business leaders was interviewed.

The statistical universe for the 'professional ecologists' was the professional membership list of the South African Institute of Ecologists. Those members living outside of the Republic of South Africa were excluded from the list, as were two members (Fuggle and Siegfried) involved in this research. The universe size was 140 , and a sample of 100 professional ecologists was interviewed.

The respondents were personally interviewed by the first author. The interview was based on a pilot-tested questionnaire covering 321 questions. Established techniques in survey design were applied (Preston, 1989). The interviewing period was from 14 December 1987 to 4 May 1988.

The data take the form of frequencies arranged in categories. Normality may not be assumed, necessitating non-parametrical tests. Appropriate tests in this analysis are Pearson's chi-square test for between-group analysis and Wilcoxon's matched-pairs signed-ranks test for within-group analysis (Siegel, 1956). Correspondence analysis, a 'perceptual mapping' multivariate technique (Greenacre, 1984 and 1986), is also used to graphically display patterns in the answers. The advantage of the Perceptual Map is that it shows the 'best fit' position of each of the variables, and gives the reader an overview of the reactions to these variables without making any assumptions about the data. The percentages on the axes of the Perceptual Map indicate the intensity of any vector by giving the proportional influence of each axis, and the sum of the percentages shows what proportion of the data is explained when compressed into a twodimensional graph.

\section{Results and discussion}

Response rates of $87 \%$ for the business leaders and $100 \%$ for the professional ecologists were achieved. These are high by international survey standards (Babbie, 1973). A professional social survey practitioner said that considering the target audiences and the time requested, these levels are exceptional for South Africa (B. Rice, pers. comm.). The 100 professional ecologists took, on average, 102 minutes to complete the full interview, while the average time for the 100 business leaders was 77 minutes.

\section{Attitudes toward corporate social funding}

The statement that business companies in South Africa should fund programmes to the benefit of society out of money that would otherwise be part of shareholders' profits elicited very strong agreement from business leaders and professional ecologists (Figure 1).

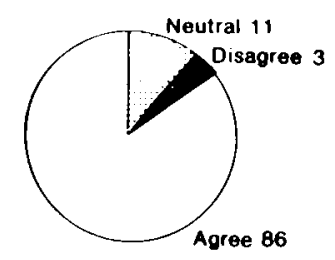

PROFESSIONAL ECOLOGISTS

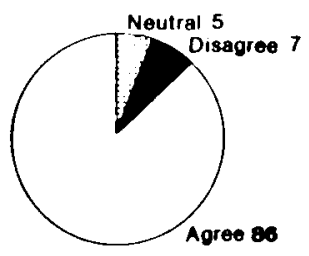

BUSINESS LEADERS
Figure 1 Responses to the statement, business companies in South Africa should fund programmes to the benefit of society out of money that would otherwise be part of shareholders' profits. $P=.94$ (Agree versus Neutral/Disagree). 
Almost all of the respondents who did not agree with the statement commented to the effect that it would be 'nice' were the companies to do so, but that the statement was too strongly worded. Two of the business leaders who disagreed did so because they thought that the phrasing of the statement should have been, 'Profitable business companies...'.

Clearly the issue was not whether to support corporate social funding, but rather the degree of support that is appropriate. Discussion revealed definite differences between the ecologists and business leaders as to what percentage of after-tax profits they thought should be devoted to corporate social funding. The answers of the ecologists fluctuated from $2 \%$ to $50 \%$, with a mean of $14,5 \%$. The range for the business leaders was from $0,75 \%$ to $10 \%$, with a mean of $3,0 \%$. Many had difficulty answering the question. Some said that it depended on the profitability and stability of the company - that one could expect a greater degree of support from an established company than from those that are 'less mature' (Dr F. du Plessis, pers. comm., et al.). Other business leaders were reluctant to prescribe for business as a whole, limiting their comments to their own companies. Still others were not prepared to answer, perhaps because they were not willing to divulge the extent of their support of social funding programmes.

Despite the difficulty of generalizing about the level of after-tax profits that should be devoted to corporate social funding, there is clearly a difference between the ecologists and business leaders as to the appropriate amount. The extent of the ecologists' knowledge of business matters is an important factor here, evidenced by the inability of some of the ecologists advocating a high after-tax percentage for corporate social funding to even vaguely approximate what such a percentage would translate to in monetary terms. (In similar vein, Bennett (1976) reported that the average Canadian believed that the manufacturer's profit in 1975 was 34 cents per sales dollar, whereas a fair profit would be 19 cents. While not knowing the overall average, he reports that the motor industry achieved 2,8 cents on the dollar.) A further factor must be that it is easier to prescribe when not bearing the responsibility, as is the situation of the ecologists. On the other hand, the business leaders are certainly not of one accord on this issue.

The business leaders, almost without exception, spoke of corporate social funding as being in their 'enlightened self-interest' (Bennett, 1976) - a common sentiment being that, 'We're funding a stable future for our corporation'. These comments were almost always directed at the socio-political spheres (in keeping with their funding programmes), rather than at the environmental sphere.

A concern raised by several ecologists was that social funding can be 'blood money'. Their contention was that a company responsible for extensive environmental degradation might attempt to buy respectability by the funding of environmental programmes, or of environmental societies that aim to be watchdogs. Such corporate funding is perceived to be a smokescreen, and possibly of far less worth than the costs of the degradation. The oil companies, in particular, appeared to suffer under this suspicion. Thus it was that several ecologists who felt that only a fraction of after-tax profits should be spent on corporate social funding qualified this with the statement that they would rather see companies being more responsible (environmentally and otherwise) in conducting their businesses. (An ironic twist here is that if such funding is a smokescreen, it may well be perceived to be in the shareholders' interests, for there would be fewer profits to be distributed were the company to take adequate environmental responsibility in its business activities!) A comparison of interest is that respondents in the survey of readers of the Harvard Business Review (Brenner and Molander, 1977), which covered broader issues of corporate social responsibility, rated 'Being an efficient user of energy and natural resources' and 'Assessing the potential environmental effects flowing from the company's technological advances' as the two most important areas of responsibility - well ahead of social funding.

While the arguments by business executives defending corporate social funding are regarded with scepticism by some commentators (e.g. Bower, 1989; Reynolds, 1989), it should be noted that several other sections of the study questioned the environmental impact of business activities (eg. Preston, Fuggle \& Siegfried, 1989a; Preston, 1989). The findings suggest that the business leaders are concerned that their companies act in an environmentally sensitive manner, within the constraints of inevitable environmental change as a result of business development. A strong sentiment was that, where possible, social costs should be absorbed into

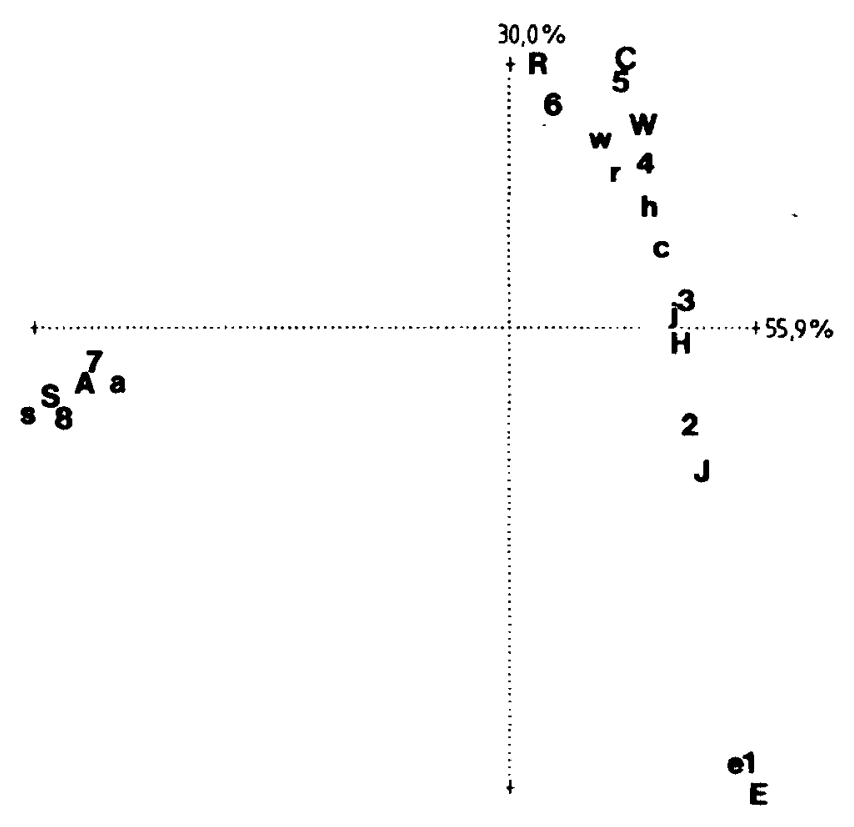

Figure 2 Perceptual Map showing the ranking of eight spheres of activity for apportioning corporate social funding. Note that the lower case symbols refer to the professional ecologists, and the upper case symbols to the business leaders. The numbers refer to the rank positions. See Table 1 for the legend explaining the symbols. 
production costs - affirming corporate social responsibility.

Of course, some business leaders are less concemed with social responsibility than are others. This quotation recounted by Fuggle (1988) illuminates the limitations of some business leaders' concern for environmental responsibility: 'In conversation with a senior executive from a large company that fosters a corporate image of being "concerned for conservation", I asked from genuine interest: "In what ways is your company able to practice conservation principles in your day to day affairs?" "Oh, we don't try to practice conservation ourselves", was the reply, "we only support conservation by giving money to the $x \times x \times$, it's their job to do the conservation"'. Such a view accords with the contention of one business leader, that 'A lack of awareness is the problem among business executives, far more so than a lack of concem'.

Whether corporate social funding should be tax deductible was raised in discussion. A few respondents, more often ecologists, believed that this is merely shifting the onus to deal with social concerns from the government to individual companies, and questioned the effectiveness of doing so. A more common stance from both groups, supportive of tax deductions, was that the South African government is inefficient and/or morally wrong in the social structures it has created, and that business companies would make a better job of such social funding. (Some business leaders said that they generated much of the money, and should have a greater say in its utilization.)
Apportionment of corporate social funding in South Africa

Given the acceptance of corporate social funding, Figure 2 shows the Perceptual Map of the ecologists and business leaders' ranking of how they would like to see corporate social funding apportioned in South Africa at present, based on the data presented in Table 1.

The ecologists revealed a particular concern for boosting education, ranking it significantly ahead of the other seven options addressed. A prevalent comment was that by boosting education, many of the other concerns (including environmental conservation) would benefit. Respondents were thus asked where the primary focus should be, given the inter-relationships and consequent ripple effects. Using the Wilcoxon matchedpairs signed-rank test, the ecologists' rating has environmental conservation significantly behind education (taken by most respondents to be primarily Black education), and significantly ahead of sport, the arts, rural development and health and welfare. There is no significant difference between the ecologists' rating of environmental conservation against job creation or housing. It is noteworthy that the ecologists' rankings do not appear to over-emphasize environmental conservation. If the arts and sport are omitted (their scant support from both groups is very apparent in their positions on the Perceptual Map), slightly more than half of the ecologists rate environmental conservation in the bottom half of the remainder of spheres.

Table 1 Overall rankings by the business leaders and professional ecologists to the question, Please rank the following eight spheres in terms of how you would like to see corporate social funding apportioned in South Africa at present. Note that the probability value is relative to environmental conservation. The legend refers to the symbols used in the perceptual map in Figure 2.

\begin{tabular}{|c|c|c|c|c|c|c|c|c|c|c|}
\hline & Busincss lenders & First & Second & Third & Fourth & Fifth & Sixth & Seventh & Eighth & Prob \\
\hline $\mathbf{E}$ & Education & 62 & 20 & 11 & 4 & 0 & 1 & 0 & 1 &.$\infty$ \\
\hline J & Job creation & 23 & 32 & 20 & 11 & 7 & 3 & 0 & 3 &.$\infty$ \\
\hline $\mathbf{H}$ & Housing & 10 & 24 & 37 & 11 & 7 & 6 & 1 & 3 & .00 \\
\hline $\mathbf{w}$ & Health \& welfare & 0 & 12 & 20 & 28 & 21 & 14 & 3 & 1 & .02 \\
\hline $\mathbf{C}$ & Env. conservation & 1 & 8 & 9 & 22 & 28 & 28 & 2 & 1 & - \\
\hline $\mathbf{R}$ & Rural development & 1 & 2 & 3 & 20 & 29 & 30 & 7 & 7 & .01 \\
\hline $\mathbf{A}$ & The arts & 1 & 2 & 0 & 2 & 4 & 6 & 45 & 39 & .00 \\
\hline \multirow[t]{2}{*}{$\mathbf{S}$} & Sport & 1 & 0 & 0 & 0 & 1 & 9 & 36 & 52 & .00 \\
\hline & Professional ecologi & & & & & & & & & \\
\hline e & Education & 59 & 21 & 9 & 6 & $\mathbf{0}$ & 2 & 0 & 3 & .00 \\
\hline $\mathbf{j}$ & Job creation & 15 & 16 & 25 & 19 & 16 & 5 & 1 & 3 & .24 \\
\hline c & Env. conservation & 8 & 21 & 19 & 22 & 14 & 13 & 2 & 1 & - \\
\hline $\mathbf{h}$ & Housing & 6 & 19 & 17 & 18 & 22 & 14 & 3 & 1 & .33 \\
\hline $\mathbf{r}$ & Rural development & 8 & 9 & 15 & 11 & 21 & 30 & 4 & 2 & .00 \\
\hline $\mathbf{w}$ & Health \& welfare & 5 & 7 & 12 & 21 & 23 & 24 & 7 & 1 & .00 \\
\hline 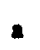 & The arts & 1 & 5 & 3 & 1 & 2 & 7 & 54 & 27 & .00 \\
\hline 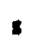 & Spon & 0 & 0 & 0 & 3 & 1 & 4 & 28 & 64 & .00 \\
\hline
\end{tabular}


A concem was that the business leaders might have ranked environmental conservation in a higher position than they genuinely believed it warranted. However, their rankings, and the manner in which they answered the question, seem to belie this. The business leaders were resolved that education be the major recipient of corporate social funding. They, too, rated environmental conservation significantly behind education, job creation and housing, as well as health and welfare, and significantly ahead of sport, the arts and rural development. Almost all of the business leaders who were asked said that their actual support of the given spheres matches their ranking of the above spheres. Of course, being a ranking, it is not possible to indicate the ratios, and a number of respondents emphasized that certain of the spheres (most often education, job creation and housing) received the vast proportion of their corporate social funding.

Respondents were asked if any other spheres of activity immediately sprung to mind as being very worthy of corporate social funding, and 38 ecologists and 32 business leaders answered 'Yes'. In most cases the answers fell within the categories given, but were recorded so as to highlight particular concems. Topping the list for the ecologists were population control (13 respondents), research (13), socio-political development (4) and urban development (4). The business leaders' chief concerns were welfare (11), socio-political development (9) and population control (7). Of interest is that only one respondent mentioned legal aid as a worthy sphere, yet a recent Financial Mail survey (1988) of a few select businesses highlighted this concern.

In a different section of the questionnaire it was established that both professional ecologists and business leaders believe that human population growth has reached a critical stage in South Africa, and is the single most serious conservation issue (Preston, Fuggle \& Siegfried, 1989b). Their disquietude is reflected in the number of times it is mentioned, although very few business leaders said that their companies are actually devoting funds to this issue. While there is evidence that raising the standard of living does impact positively on population control, a strong argument can be made for population growth being a root cause of socio-economic concerns such as unemployment, inadequate education and training skills, housing shortages, and insufficient

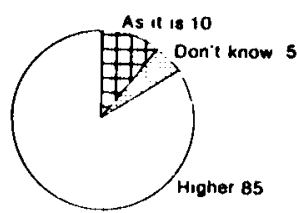

PROFESSIONAL ECOLOGISTS

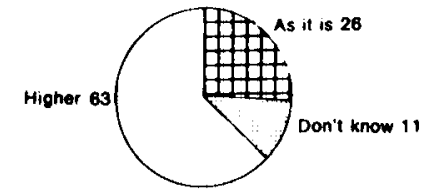

BUSINESS LEADERS
Figure 3 Responses to the question Do you think that the current contribution of corporate social funding to environmental conservation in Souh Africa should be higher, or lower, or about the level it is?

$P<.01$ (Higher versus As it is). provision for health and welfare. These are reasons why the low level of actual support for population contol is regarded with apprehension by professional ecologists.

In this same section it was found that both groups rated environmental conservation as of lesser priority than education, job creation and housing as serious issues facing South Africa, with the business leaders also feeling that health and welfare was more important. The business leaders' rankings of spheres worthy of corporate social funding are thus in line with what they see as the priority issues in South Africa. The professional ecologists, on the other hand, would seem to differentiate more between the priorities for government funding and corporate social funding. They rated health and welfare and environmental conservation as equal priority issues in South Africa, yet felt that more corporate social funding should be devoted to the latter. Similarly, they regard job creation and housing to be greater priority issues than environmental conservation, but feel they should be equal beneficiaries of corporate social funding. It should be noted that some business leaders felt that certain spheres were the responsibility of the government, and are outside of the ambit of corporate social funding (e.g. the business leader who ranked education eighth - see Table 1). This might account for their low emphasis on corporate social funding of rural development - also considered by both groups to be among the most important foci for environmental conservation in South Africa (Preston, Fuggle \& Siegfried, 1989b).

\section{Corporate social funding of environmental conservation} Most ecologists believed that the current contribution of corporate social funding to environmental conservation in South Africa should be higher. Although this viewpoint was not as strongly supported by the business leaders, there were nonetheless significantly more among them who favoured a higher contribution than those advocating that it should stay as it is and those responding 'Don't Know'. No respondent in either group thought that it should be lower (Figure 3).

When asked what was stopping them devoting more to environmental conservation, business leaders favouring a higher contribution said that their company was making an appropriate contribution, but that other companies were not doing so. Two of the respondents pointed to company image as the reason for a funding programme

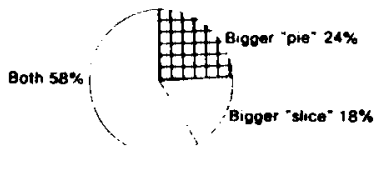

PROFESSIONAL ECOLOGISTS

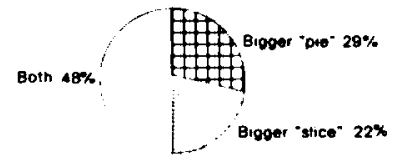

BUSINESS LEADERS
Figure 4 Responses to the question, If higher, should this be brought about by environmental conservation having a bigger slice of the corporate social funding 'pie', or by increasing the size of the pie, or both (a bigger slice of a bigger pie)? $\mathrm{P}=.40$ (d.f. $=2$ ). 
84

out of focus with their preferred allocation - one saying, 'Environmental conservation is low in Sullivan Code Brownie Points'.

Most of the ecologists and business leaders who agreed that the contribution to conservation should be higher said that this should be brought about by a bigger slice of a bigger pie (Figure 4).

By extrapolation, this means that at least $69 \%$ of the ecologists, and $48 \%$ of the business leaders, believe that the level of corporate social funding in South Africa is insufficient. (This is a minimum figure, as respondents may think that the overall contribution is too small but that spheres other than environmental conservation should be the beneficiaries.) Most of those saying that conservation should get a bigger slice of the pie said that this should be at the expense of spheres they rated as lower, most usually the arts and sport. However, some said that it could be at the expense of some higher-rated spheres, without this changing their ranked order.

\section{Shareholders reactions to corporate social funding}

The professional ecologists were irresolute as to whether shareholders in listed companies in South Africa would not favour the company supporting conservation through a corporate social fund. This is perhaps indicative of the lack of interaction with business by some of the ecologists. However, the business leaders were very much more sure of their mandate (Figure 5).

This assurance of their mandate is typified in the views of O'Dowd (1989), who points to explicit provision for corporate social funding in the Articles of Association, and adds, 'In all the years I have been connected with the Anglo American Corporation Group Chairman's Fund, the number of letlers received from shareholders objecting to its operations can be counted on the fingers of one hand'.

\section{Within-group analysis}

Establishing the significant determinants of differences within the two groups is hampered by the small sample sizes (even though the samples represent over $70 \%$ of the individuals in each of the universes). No one condition variable revealed a significant difference for more than one question. For example, those business leaders from 'primary impact' businesses were significantly more in favour $(\mathrm{P}=.05)$ that the current contribution of corporate social funding to environmental conservation in South Africa should be higher than were the 'secondary impact' business leaders. However, the likelihood of differences occurring by chance when testing so many condition variables makes it prudent to treat such variation with circumspection.

\section{Conclusions}

Widespread support for the notion of corporate social funding is revealed in this survey, although there are significant differences between, and within, the professional ecologists and business leaders as to an appropriate level of support. There is sympathy for such funding to be tax deductible.

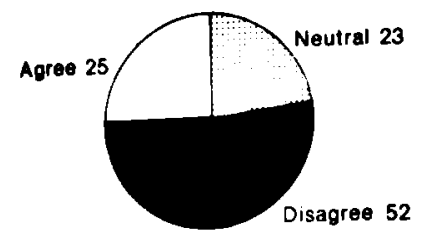

PROFESSIONAL ECOLOGISTS

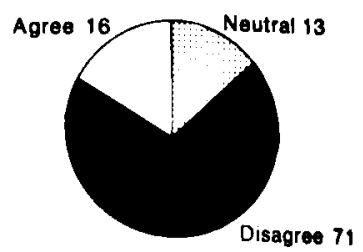

BUSINESS LEADERS
Figure 5 Responses to the statement, Shareholders in listed companies in South Africa would not favour the company supporting conservation through a corporate social fund. $\mathrm{P}=$ .01 (Agree/Neural versus Disagree).

A definite difference in emphasis for corporate social funding emerges, with the ecologists regarding support of environmental conservation to be more pressing, relative to other concerns, than do the business leaders. The professional ecologists appear to believe that corporate social funding should concern itself less with health and welfare, job creation and housing and more with environmental conservation, relative to their statuses as priority issues in South Africa. The business leaders, on the other hand, mirror their corporate social funding priorities on what they regard as the priority issues in South Africa - effectively backing-up government efforts to address these issues.

The greatest disparity between the two groups is that the ecologists regard environmental conservation as being worthy of greater corporate social funding than health and welfare, whereas the business leaders rank them the other way around. Furthermore, ecologists would have environmental conservation on a par with job creation and housing, while business leaders would not give it as big a slice of the corporate social funding pie. Both groups regard environmental conservation as a more needy cause to support than rural development, although the ecologists place a greater emphasis on this sphere than do the business leaders. The arts and sport are not deemed to be priority spheres by either groups.

Despite rating the need to support environmental conservation as less important than some other concerns, the majority of business leaders agreed that it should be receiving greater funding from companies. They voiced support for increasing the overall level of corporate social funding by business companies, and hence benefitting environmental conservation, as well as for increasing the proportion of the overall funding it receives. A stronger majority of ecologists concurred with these views. The consensus was that shareholders would support this directive, although many of the ecologists did not regard themselves as competent to judge this.

The responses of both groups to corporate social funding in general, and of environmental conservation in particular, appear to be balanced assessments from divergent perspectives. Evidence of a genuine regard for environmental concems by business leaders is referred to - suggesting that corporate social funding of environmental conservation (inter alia) is not merely 
'blood money'. For their part, the professional ecologists do not over-emphasise environmental conservation as a cause for corporate social funding.

The regard for corporate social funding support of population control, acknowledged to be the most serious conservation issue in South Africa at present, and at the root of many socioeconomic concerns, is offset by the low level of actual support for this issue.

\section{Acknowledgements}

Funding from the University of Cape Town, the Human Sciences Research Council, the Siri Johnson bursary, Reader's Digest Association (South Africa), and the Londolozi Game Reserve is gratefully acknowledged. Mr G.W.H. Relly, in his capacity as chairman of the South African Nature Foundation, is thanked for his endorsement of this research.

Many people assisted in this research, and they are thanked elsewhere (Preston, 1989). For this paper, the contributions of Penny Brown, John Fowkes, Jannie Hofmeyr, John Raimondo, Butch Rice, Andy Vinnicombe, and all of those who gave up their time to be interviewed, are appreciated.

\section{References}

Babbie E.R. 1973. Survey research methods. Belmont, California: Wadsworth Publishing Company

Bennett R.F. 1976. Business and social responsibility, Cost and Management, Sept-Oct, 1976: 14-16.

Bower C. 1989. Social responsibility: Stop the pretence, The Executive, Febr 1989: 38-41.

Brenner S.N. \& Molander E.A. 1977. Is the ethics of business changing? Harv. Bus. Rev. vol. 55: 57-71.

Financial Mail. 1987. Top companies. Supplement to Financial Mail, 22 May.

Financial Mail. 1989. Corporate social responsibility - A survey. Supplement to Financial Mail, 3 Febr.

Friedman M. 1962. Capitalism and freedom. Chicago: University of Chicago.

Fuggle R.F. 1988. Conservation ethics: Should wildlife society members be required to subscribe to a code of ethics? Conference proceedings - priorities for conservation in
South Africa. The Wildlife Society of Southern Africa. Durban, 17 Sept.

Greenacre MJ. 1984. Theory and application of correspondence analysis. London: Academic Press.

Greenacre MJ. 1986. SIMCA: A program to perform simple correspondence analysis. American Statistician, vol. 51: 230-231.

Leatt J. 1984. Corporate responsibility and South Africa's political economy: Philanthropy or the exercise of power? Inaugural lecture 98, University of Cape Town.

O'Dowd M. 1989. The case for corporate donations. The Execulive, March 1989: 23-26.

Preston G.R. (1989). Autitudes of professional ecologists and business leaders toward conservation and development in Soulh Africa. Unpublished PhD thesis, University of Cape Town.

Preston G.R., Fuggle R.F. and Siegfried W.R. (a) (1989). Attitudes of business leaders and professional ecologists to environmental evaluations in South Africa. S. Afr. J. Science, 85(7): $430-434$

Preston G.R., Fuggle R.F. and Siegfried W.R. (b) (1989) Environmental issues in South Africa: Perceptions of professional ecologists and business leaders. S. Afr. J. Wildlife Research, 19(4): 145-155.

Preston G.R., Fuggle R.F. and Siegfried W.R. (c) (In Press). Attitudes of professional ecologists and business leaders toward regulating the utilization of natural resources in South Africa. Development Soush Africa.

Preston G.R., Fuggle R.F. and Siegfried W.R. (d) (In Press). Socio-political attitudes of professional ecologists and business leaders in South Africa. Indicator.

Preston G.R., Fuggle R.F. and Siegfried W.R. (e) (In Press).Business leaders and professional ecologists: Toward common ground. In Man and the Environment (ed. T. Hart), Human Sciences Research Council, Pretoria.

Reynolds L.G. 1989. Rupert gave away more than he knew. Letter in the Cape Times, 6 Apr.

Siegel S. 1956. Nonparametric Statistics for the Behavioural Sciences. Tokyo: McGraw-Hill.

Smith A. 1976. An enquiry inso the nature and causes of the wealth of nations. Modem Library, New York. 